\title{
Review
}

\section{New Beginnings in Alzheimer's Disease: The Most Prevalent Tauopathy}

\author{
Félix Hernández ${ }^{\mathrm{a}, \mathrm{b}}$, María Llorens-Martín ${ }^{\mathrm{a}, \mathrm{b}, \mathrm{e}}$, Marta Bolós ${ }^{\mathrm{a}, \mathrm{b}}$, Mar Pérez $^{\mathrm{c}}$, Raquel Cuadros ${ }^{\mathrm{a}, \mathrm{b}}$, \\ Noemí Pallas-Bazarra ${ }^{\mathrm{a}, \mathrm{b}}$, Juan C. Zabala ${ }^{\mathrm{d}}$ and Jesús Avila ${ }^{\mathrm{a}, \mathrm{b}, *}$

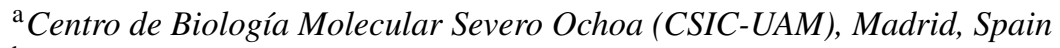 \\ ${ }^{\mathrm{b}}$ CIBERNED, Madrid, Spain \\ ${ }^{\mathrm{c}}$ Departamento de Anatomía Histología y Neurociencia, Facultad de Medicina UAM, Madrid, Spain \\ ${ }^{\mathrm{d}}$ Departamento de Biología Molecular, Facultad de Medicina, Universidad de Cantabria, Santander, Spain \\ ${ }^{\mathrm{e}}$ Department of Molecular Biology, Faculty of Science, Universidad Autonoma de Madrid, Spain
}

\begin{abstract}
Alzheimer's disease (AD) is characterized by the presence of two aberrant structures: namely senile plaques, composed of amyloid- $\beta$ peptide $(A \beta)$, and neurofibrillary tangles, composed of tau protein. In this regard, $A \beta$ and tau protein have been widely studied in research efforts aiming to find a therapy for AD. A $\beta$ and tau pathologies do not always overlap. The precursor of $A \beta$ is expressed in peripheral tissues and in the central nervous system (CNS), whereas tau is mainly a neuronal protein. Since AD is a disease of the CNS, it has been proposed that A $\beta$ may initiate the disease process, with tau being the executor. In this review, we will focus on future studies of tau pathology, although we will comment on new beginnings for $\mathrm{AD}$, as other molecules other than $\mathrm{A} \beta$ and tau may be involved in the onset of dementia.
\end{abstract}

Keywords: Extracellular tau, MAPs, tau functions, tauopathies

\section{INTRODUCTION}

One hundred years ago, Alzheimer's disease (AD) was described as a condition involving the presence of senile plaques (A $\beta$ aggregates), neurofibrillary tangles (tau protein polymers), and neuronal death [1]. Thus, the development of $A \beta$ and tau pathologies does not overlap, with Thal stages [2] of the former differing from Braak stages [3] of the latter. In this review, we will focus on tau pathology.

$\mathrm{AD}$ is the most prevalent tauopathy; tauopathies are diseases involving a dysfunction of tau protein, through a loss of function or a gain of toxic function. Research involving mouse models revealed that the

*Correspondence to: Jesús Avila, Centro de Biología Molecular Severo Ochoa (CSIC-UAM), 28049 Madrid, Spain. E-mail: javila@cbm.csic.es. lack of tau does not cause death or clear neurodegeneration $[4,5]$. It is therefore assumed that tauopathies like $\mathrm{AD}$ are the consequences of a gain of toxic function $[6,7]$, which may be related to the accumulation of modified or unmodified tau in neurons, among other features [8].

\section{AD IS CHARACTERIZED BY A HIGHER AMOUNT OF TAU PROTEIN}

The brains of AD patients show a greater accumulation of tau protein compared with those of healthy counterparts [9]. This increase in tau may result from an increased transcription of mapt gene, an increase in the translation of tau protein, or a deficient tau degradation [10-13]. Among signaling pathways, mTOR may participate in an increased translation and a 
decreased degradation of tau protein. This notion is supported by the observation of increased mTOR signaling in the brains of AD patients [14]. This activation of mTOR may trigger mRNA translation into tau protein through the recognition of a terminal of oligopyrimidine track ( $5^{\prime}$-TOP) sequence present at the 5'UTR of mapt RNA [10].

On the other hand, mTOR1 activation inhibits autophagy [15], thereby possibly impairing tau protein degradation. In addition, tau expression may depend on tau haplotype (H1 or H2) [16] or on the presence of miRNAs that bind to the 3'UTR mapt mRNA $[17,18]$. Regarding protein degradation, AD involves impaired proteasome [11], and modified (aggregated or phosphorylated) tau may inhibit proteasome or autophagy functions. The current working hypothesis is that tau accumulation is caused mainly by deficient protein degradation rather than by an increase in the expression of this protein. A lower tau turnover may facilitate tau phosphorylation by various kinases or its modification by truncation (upon cleavage with several proteases), acetylation, glycation, or other posttranslational modifications that also result in the accumulation of modified tau [8]. Some of these modified forms are toxic when present in neurons. Thus, the long life (due to a lower turnover) of intracellular tau may have negative consequences. In addition, distinct ratios of tau isoforms containing three (tau 3R) or four (tau 4R) tubulin-binding repeats, arising by a different splicing of nuclear mapt RNA, could result in a toxic effect promoting tauopathies such as Huntington's disease [19]. Splicing mechanisms can give rise to a number of different tau isoforms [20], and their involvement in neuronal toxicity deserves further attention.

\section{HOW DOES THE BRAIN DEAL WITH AN INCREASE IN INTRACELLULAR TAU IN AD?}

Since the proportion of tubulin in brain is much higher than that of tau protein (or other microtubuleassociated proteins, MAPs), a slight increase in brain tau can result in an additional interaction of the protein with the available open sites present in neuronal microtubules. This interaction will lead to a greater tau/tubulin ratio in polymerized microtubules when the increase in tau is through an excess of the functional unmodified form. In this case, the increased in tau also leads to competition with other molecules or organelles (like mitochondria) for the same microtubule binding sites [21]. Such competition may affect the transport (mediated by microtubules) of these organelles, in a similar way to the effect found in other MAPs [22].

A further increase in neuronal tau can lead to a change in the subcellular localization of this protein. Tau is preferentially distributed in the axonal compartment [23], but an increase in this protein favors its localization to somatic dendritic compartments [24]. In addition, an increase in the level of intracellular tau may result in its secretion to the extracellular space [25], where it can be toxic for neighboring neurons and can propagate throughout the brain [26, 27]. In this case, tau might be secreted in an unmodified or modified (truncated or aggregated) form [28].

One strategy through which to tackle the increase in intracellular tau is to reduce its expression or to increase its degradation by acting on mTOR pathway. Alternatively, tau expression could be decreased by increasing the expression of miRNAs, like miRNA129, thereby reducing its translation [18].

\section{HUMAN TAU AND TAU OF OTHER ORIGINS: DO THEY PLAY A DIFFERENT ROLE IN TAUOPATHIES?}

A review entitled "The exceptional vulnerability of humans to Alzheimer's disease" has recently been published [29]. This review reports that an increased vulnerability of human tau, compared with tau proteins from other sources, cannot be discarded. In this regard, it is therefore pertinent to study not only the increased expression of tau but also its structural nature. Several studies have been carried out to compare the structural differences or changes in posttranslational modifications of tau protein of distinct origins [30, 31]. Some studies have also addressed changes in posttranslational modifications, but further analysis is required to gain a broader understanding of this point [32].

\section{EXTRACELLULAR TAU}

As previously indicated, an increase in the level of intracellular tau results in its secretion [25] or, in a few cases, neuron death [26]. In both scenarios, it also leads to the presence of extracellular tau, a toxic molecule [26]. Various mechanisms of tau exocytosis (secretion) have been proposed [32-35]. In some cases, soluble unmodified tau is secreted while in others modified (truncated, phosphorylated, 
aggregated, etc.) tau is released from the cell. Such release is through a naked form or through exosomes [25]; however, it has also been put forward that this release occurs through tunneling nanotubes [34]. Extracellular tau also interacts with surrounding neurons and can be internalized via various endocytotic pathways. Depending on whether tau is in an unmodified or modified form, it binds to cellular receptors (muscarinic receptors M1/M3) [27] or to components of the extracellular matrix, like heparan sulphate [33], respectively. Also, research efforts should address whether other mechanisms of endocytosis are involved [36].

In addition, extracellular tau interacts with glial cells. In this regard, mainly the interaction of tau with microglia has been analyzed [37], and preliminary data suggest that this interaction occurs from different receptors to those previously described for neurons, despite the presence of muscarinic M3 receptors in a small population of microglia [38]. Also, some components of the extracellular matrix, like heparan sulphate, are present in microglia. However, results from preliminary studies support the notion that a novel tau receptor is located in resting microglia.

Thus, an increase in intracellular or extracellular tau may have negative consequences. In the case of extracellular tau, it can be cleared through the action of microglia; however, these cells lose some of their functional characteristics in tauopathies like AD [39]. Although blocking the cellular receptors needed for tau binding has been proposed [27], current research efforts are focused on the development of tau vaccines $[40,41]$. Future studies are expected to determine the potential of these vaccines to prevent the toxicity and propagation of extracellular tau.

\section{CONSEQUENCES OF TAU ELIMINATION IN NEURONAL CELLS}

We have previously proposed that therapeutic strategies for tauopathies like AD should involve reducing the level of intracellular tau or clearing extracellular tau. In this regard and given that mouse models have revealed that the absence of the protein does not affect viability or stimulate neurodegenerative disorders $[4,5]$, one therapeutic approach could be to remove the whole tau protein. However, the absence of tau may result in the loss of some functional characteristics of tau-deficient mice.

It has been proposed that intracellular tau exerts several functions. For example, tau protein, which is a MAP, favors the assembly of microtubules in vitro [8]. Its presence results in decreased microtubule dynamics and an increase in microtubule stability [42]. Also, tau regulates the number of protofilaments in microtubules [43]. In contrast to other proteins, like EB proteins, which bind at the GTP-tubulinrich microtubule tips, tau shows greater binding affinity to GDP like-tubulin conformations [44]. On the other hand, the cross-talk of tau with EB proteins has been shown to regulate axon extension in developing neurons [45]. Also, interaction between EB1 and tau protein is postulated to regulate axonal tau sorting [24]. However, some of these tau functions are complemented in tau knockout mice by the presence of other proteins and neuron differentiation is delayed but not impaired in tau-deficient mice [5].

More specifically, the loss of tau results in an increase in wakefulness duration and decreased NREM sleep [46]. Also, tau knockout mice show shaking and other features of Parkinsonism [47, 48], In addition, these animals exhibit brain insulin resistance [49] and alterations of cardiovascular functions [50].

A main consequence of tau loss has been found at the apical dendrites of newborn granule cells present in the dentate gyrus. In tau knockout mice, dendritic spines do not grow when the mouse is exposed to an enrichment environment (which usually occurs in wild-type mice). Also, the loss of dendritic spines in these apical dendrites in wild-type mice under stress is not observed in the tau knockout model [51]. These results indicate a novel function of tau protein related to synaptic plasticity, thereby suggesting that this molecule is a synaptic plasticity modulator for positive or negative external stimuli [51].

Furthermore, it is known that the presence of tau in dendritic spines regulates the toxic effect of $A \beta$ in neurons [52]. In this regard, A $\beta$ peptide, Glu N2B (a subunit of NMDA receptor), tyrosine kinase fyn, and PSD-95 (postsynaptic protein) are involved in this process [52]. Despite the action of $A \beta$, it has also been proposed that tau-fyn-GluN2B regulates the activity of CREB, a protein related to memory and learning [53].

Since AD is considered a synaptopathy, in-depth analysis of the role (positive and negative) of tau in synaptic connections is required. Independently of tau, the use of compounds to prevent synaptic deficits is not straightforward, since many pharmaceutical agents should not cross the blood-brain barrier (BBB). Nevertheless, some BBB-permeable 
compounds, like a modified peptide of the ciliary neurotrophic factor, can rescue synaptic deficits [54].

\section{FUTURE DIRECTIONS AND NEW BEGINNINGS}

Regarding tau pathology, research appears to be focused on ways to decrease the level of intracellular tau-mainly the toxic modified tau forms (phosphorylation, truncation, aggregation, etc.) -in neurons. In the case of extracellular tau clearance, the development of vaccines emerges as a major objective [40]. However, such vaccines should be administered at the most appropriate stage of $\mathrm{AD}$ development. In this regard, this disease is characterized by three developmental stages: an asymptomatic stage, related to amyloid pathology; a transition step from nondemented to mild cognitive impairment, related to tau pathology; and a third stage involving the development of dementia and related to neuron death and glia activation (inflammation). Once tau pathology is evident, the use of compounds against amyloid pathology is probably no longer suitable. Also, after neuron death, the use of compounds against tau pathology could be useless. It is therefore important to treat each pathology in a timely manner. To achieve this, it is necessary to have access to early biomarkers, thereby allowing treatment at the onset of the disease.

Moreover, the therapeutic focus in AD has fallen mainly on two targets, namely $\mathrm{A} \beta$ and tau. However, other targets that remain to be identified may facilitate the onset of the disease. In this regard, potential new targets deserve attention.

These possible novel factors include brain somatic mutations that may be related to processes associated with $\mathrm{A} \beta$ or tau pathologies. In this regard, some reports have described single nucleotide variations in brain tissue of AD patients [55, 56]. Also, inserts, deletions, and transposons [57-59] related to the appearance of AD deserve attention. Also, further analysis should be devoted to epigenetic changes [60], in the search for alternative therapies [61].

Finally, this short summary makes no reference to damage in neuronal circuits or complementation between circuits (which could delay the appearance of the disease) [62], the possible deficits related to the disease that correlate with impaired adult neurogenesis [63], or attempts to delay the onset of the disease by slowing down the aging process, since the main risk for $\mathrm{AD}$ is aging [64].

\section{DISCLOSURE STATEMENT}

Authors' disclosures available online (https:// www.j-alz.com/manuscript-disclosures/17-9916).

\section{REFERENCES}

[1] Alzheimer A (1907) Uber eine eigenartige Erkankung der Hirnrinde. Psych Genchtl Med 64, 146-148.

[2] Thal DR, Rub U, Orantes M, Braak H (2002) Phases of A beta-deposition in the human brain and its relevance for the development of AD. Neurology 58, 1791-1800.

[3] Braak H, Braak E (1991) Neuropathological stageing of Alzheimer-related changes. Acta Neuropathol 82, 239-259.

[4] Chen J, Kanai Y, Cowan NJ, Hirokawa N (1992) Projection domains of MAP2 and tau determine spacings between microtubules in dendrites and axons. Nature 360, 674-677.

[5] Dawson HN, Ferreira A, Eyster MV, Ghoshal N, Binder LI, Vitek MP (2001) Inhibition of neuronal maturation in primary hippocampal neurons from tau deficient mice. J Cell Sci 114, 1179-1187.

[6] Rapoport M, Dawson HN, Binder LI, Vitek MP, Ferreira A (2002) Tau is essential to beta -amyloid-induced neurotoxicity. Proc Natl Acad Sci U S A 99, 6364-6369.

[7] Roberson ED, Scearce-Levie K, Palop JJ, Yan F, Cheng IH, Wu T, Gerstein H, Yu GQ, Mucke L (2007) Reducing endogenous tau ameliorates amyloid beta-induced deficits in an Alzheimer's disease mouse model. Science 316, 750754.

[8] Avila J, Lucas JJ, Perez M, Hernandez F (2004) Role of tau protein in both physiological and pathological conditions. Physiol Rev 84, 361-384.

[9] Khatoon S, Grundke-Iqbal I, Iqbal K (1992) Brain levels of microtubule-associated protein tau are elevated in Alzheimer's disease: A radioimmuno-slot-blot assay for nanograms of the protein. J Neurochem 59, 750-753.

[10] Morita T, Sobue K (2009) Specification of neuronal polarity regulated by local translation of CRMP2 and Tau via the mTOR-p70S6K pathway. J Biol Chem 284, 27734-27745.

[11] Keller JN, Hanni KB, Markesbery WR (2000) Impaired proteasome function in Alzheimer's disease. J Neurochem 75, 436-439.

[12] Wang Y, Mandelkow E (2012) Degradation of tau protein by autophagy and proteasomal pathways. Biochem Soc Trans 40, 644-652.

[13] Garcia-Escudero V, Gargini R, Martin-Maestro P, Garcia E, Garcia-Escudero R, Avila J (2017) Tau mRNA 3'UTR-toCDS ratio is increased in Alzheimer disease. Neurosci Lett 655, 101-108.

[14] Sun YX, Ji X, Mao X, Xie L, Jia J, Galvan V, Greenberg DA, Jin K (2014) Differential activation of mTOR complex 1 signaling in human brain with mild to severe Alzheimer's disease. J Alzheimers Dis 38, 437-444.

[15] Dickson JR, Kruse C, Montagna DR, Finsen B, Wolfe MS (2013) Alternative polyadenylation and miR-34 family members regulate tau expression. $J$ Neurochem 127 , 739-749.

[16] Caffrey TM, Wade-Martins R (2007) Functional MAPT haplotypes: Bridging the gap between genotype and neuropathology. Neurobiol Dis 27, 1-10.

[17] Caillet-Boudin ML, Buee L, Sergeant N, Lefebvre B (2015) Regulation of human MAPT gene expression. Mol Neurodegener 10, 28. 
[18] Santa-Maria I, Alaniz ME, Renwick N, Cela C, Fulga TA, Van Vactor D, Tuschl T, Clark LN, Shelanski ML, McCabe BD, Crary JF (2015) Dysregulation of microRNA-219 promotes neurodegeneration through post-transcriptional regulation of tau. J Clin Invest 125, 681-686.

[19] Fernandez-Nogales M, Cabrera JR, Santos-Galindo M, Hoozemans JJ, Ferrer I, Rozemuller AJ, Hernandez F, Avila J, Lucas JJ (2014) Huntington's disease is a four-repeat tauopathy with tau nuclear rods. Nat Med 8, 881-885.

[20] Andreadis A (2005) Tau gene alternative splicing: Expression patterns, regulation and modulation of function in normal brain and neurodegenerative diseases. Biochim Biophys Acta 1739, 91-103.

[21] Llorens-Martin M, Lopez-Domenech G, Soriano E, Avila J (2011) GSK3beta is involved in the relief of mitochondria pausing in a tau-dependent manner. PLoS One 6, e27686.

[22] Jimenez-Mateos EM, Gonzalez-Billault C, Dawson HN, Vitek MP, Avila J (2006) Role of MAP1B in axonal retrograde transport of mitochondria. Biochem $J$ 397, 53-59.

[23] Dotti CG, Banker GA, Binder LI (1987) The expression and distribution of the microtubule-associated proteins tau and microtubule-associated protein 2 in hippocampal neurons in the rat in situ and in cell culture. Neuroscience 23, 121-130.

[24] Zempel H, Dennissen FJA, Kumar Y, Luedtke J, Biernat J, Mandelkow EM, Mandelkow E (2017) Axodendritic sorting and pathological missorting of Tau are isoform-specific and determined by axon initial segment architecture. J Biol Chem 292, 12192-12207.

[25] Simon D, Garcia-Garcia E, Royo F, Falcon-Perez JM, Avila J (2012) Proteostasis of tau. Tau overexpression results in its secretion via membrane vesicles. FEBS Lett 586, 47-54.

[26] Gomez-Ramos A, Diaz-Hernandez M, Cuadros R, Hernandez F, Avila J (2006) Extracellular tau is toxic to neuronal cells. FEBS Lett 580, 4842-4850.

[27] Gomez-Ramos A, Diaz-Hernandez M, Rubio A, MirasPortugal MT, Avila J (2008) Extracellular tau promotes intracellular calcium increase through M1 and M3 muscarinic receptors in neuronal cells. Mol Cell Neurosci 37, 673-681.

[28] Clavaguera F, Bolmont T, Crowther RA, Abramowski D, Frank S, Probst A, Fraser G, Stalder AK, Beibel M, Staufenbiel M, Jucker M, Goedert M, Tolnay M (2009) Transmission and spreading of tauopathy in transgenic mouse brain. Nat Cell Biol 11, 909-913.

[29] Walker LC, Jucker M (2017) The exceptional vulnerability of humans to Alzheimer's disease. Trends Mol Med 23, 534545.

[30] Nelson PT, Stefansson K, Gulcher J, Saper CB (1996) Molecular evolution of tau protein: Implications for Alzheimer's disease. J Neurochem 67, 1622-1632.

[31] Leon-Espinosa G, Garcia E, Gomez-Pinedo U, Hernandez F, DeFelipe J, Avila J (2016) Decreased adult neurogenesis in hibernating Syrian hamster. Neuroscience 333, 181-192.

[32] Lee VM, Goedert M, Trojanowski JQ (2001) Neurodegenerative tauopathies. Annu Rev Neurosci 24, 1121-1159.

[33] Holmes BB, DeVos SL, Kfoury N, Li M, Jacks R, Yanamandra K, Ouidja MO, Brodsky FM, Marasa J, Bagchi DP, Kotzbauer PT, Miller TM, Papy-Garcia D, Diamond MI (2013) Heparan sulfate proteoglycans mediate internalization and propagation of specific proteopathic seeds. Proc Natl Acad Sci U S A 110, E3138-E3147.

[34] Goedert M, Clavaguera F, Tolnay M (2010) The propagation of prion-like protein inclusions in neurodegenerative diseases. Trends Neurosci 33, 317-325.
[35] Goedert M, Spillantini MG (2017) Propagation of Tau aggregates. Mol Brain 10, 18.

[36] Simunovic M, Manneville JB, Renard HF, Evergren E, Raghunathan K, Bhatia D, Kenworthy AK, Voth GA, Prost J, McMahon HT, Johannes L, Bassereau P, Callan-Jones A (2017) Friction mediates scission of tubular membranes scaffolded by BAR proteins. Cell 170, 172-184 e111.

[37] Bolos M, Llorens-Martin M, Jurado-Arjona J, Hernandez F, Rabano A, Avila J (2016) Direct evidence of internalization of tau by microglia in vitro and in vivo. J Alzheimers Dis 50, 77-87.

[38] Pannell M, Meier MA, Szulzewsky F, Matyash V, Endres M, Kronenberg G, Prinz V, Waiczies S, Wolf SA, Kettenmann H (2016) The subpopulation of microglia expressing functional muscarinic acetylcholine receptors expands in stroke and Alzheimer's disease. Brain Struct Funct 221, 1157-1172.

[39] Keren-Shaul H, Spinrad A, Weiner A, Matcovitch-Natan O, Dvir-Szternfeld R, Ulland TK, David E, Baruch K, LaraAstaiso D, Toth B, Itzkovitz S, Colonna M, Schwartz M, Amit I (2017) A unique microglia type associated with restricting development of Alzheimer's disease. Cell 169, 1276-1290 e1217.

[40] Sigurdsson EM (2016) Tau immunotherapy. Neurodegener Dis 16, 34-38.

[41] Nobuhara CK, DeVos SL, Commins C, Wegmann S, Moore BD, Roe AD, Costantino I, Frosch MP, Pitstick R, Carlson GA, Hock C, Nitsch RM, Montrasio F, Grimm J, Cheung AE, Dunah AW, Wittmann M, Bussiere T, Weinreb PH, Hyman BT, Takeda S (2017) Tau antibody targeting pathological species blocks neuronal uptake and interneuron propagation of tau in vitro. Am J Pathol 187, 1399-1412.

[42] Panda D, Samuel JC, Massie M, Feinstein SC, Wilson L (2003) Differential regulation of microtubule dynamics by three- and four-repeat tau: Implications for the onset of neurodegenerative disease. Proc Natl Acad Sci U S A 100, 9548-9553.

[43] Choi MC, Raviv U, Miller HP, Gaylord MR, Kiris E, Ventimiglia D, Needleman DJ, Kim MW, Wilson L, Feinstein SC, Safinya CR (2009) Human microtubule-associatedprotein tau regulates the number of protofilaments in microtubules: A synchrotron X-ray scattering study. Biophys J 97, 519-527.

[44] Duan AR, Jonasson EM, Alberico EO, Li C, Scripture JP, Miller RA, Alber MS, Goodson HV (2017) Interactions between tau and different conformations of tubulin: Implications for tau function and mechanism. J Mol Biol 429, 1424-1438.

[45] Sayas CL, Tortosa E, Bollati F, Ramirez-Rios S, Arnal I, Avila J (2015) Tau regulates the localization and function of End-binding proteins 1 and 3 in developing neuronal cells. J Neurochem 133, 653-667.

[46] Cantero JL, Hita-Yanez E, Moreno-Lopez B, Portillo F, Rubio A, Avila J (2010) Tau protein role in sleep-wake cycle. $J$ Alzheimers Dis 21, 411-421.

[47] Lei P, Ayton S, Finkelstein DI, Spoerri L, Ciccotosto GD, Wright DK, Wong BX, Adlard PA, Cherny RA, Lam LQ, Roberts BR, Volitakis I, Egan GF, McLean CA, Cappai R, Duce JA, Bush AI (2012) Tau deficiency induces parkinsonism with dementia by impairing APP-mediated iron export. Nat Med 18, 291-295.

[48] Zheng M, Jiao L, Tang X, Xiang X, Wan X, Yan Y, Li X, Zhang G, Li Y, Jiang B, Cai H, Lin X (2017) Tau haploinsufficiency causes prenatal loss of dopaminergic neurons 
in the ventral tegmental area and reduction of transcription factor orthodenticle homeobox 2 expression. FASEB $J \mathbf{3 1}$, 3349-3358.

[49] Marciniak E, Leboucher A, Caron E, Ahmed T, Tailleux A, Dumont J, Issad T, Gerhardt E, Pagesy P, Vileno M, Bournonville C, Hamdane M, Bantubungi K, Lancel S, Demeyer D, Eddarkaoui S, Vallez E, Vieau D, Humez S, Faivre E, Grenier-Boley B, Outeiro TF, Staels B, Amouyel P, Balschun D, Buee L, Blum D (2017) Tau deletion promotes brain insulin resistance. J Exp Med 214, 2257-2269.

[50] Betrie AH, Ayton S, Bush AI, Angus JA, Lei P, Wright CE (2017) Evidence of a cardiovascular function for microtubule-associated protein tau. J Alzheimers Dis 56, 849-860.

[51] Pallas-Bazarra N, Jurado-Arjona J, Navarrete M, Esteban JA, Hernandez F, Avila J, Llorens-Martin M (2016) Novel function of tau in regulating the effects of external stimuli on adult hippocampal neurogenesis. EMBO J 35, 1417-1436.

[52] Ittner LM, Ke YD, Delerue F, Bi M, Gladbach A, van Eersel J, Wolfing H, Chieng BC, Christie MJ, Napier IA, Eckert A, Staufenbiel M, Hardeman E, Gotz J (2010) Dendritic function of tau mediates amyloid-beta toxicity in Alzheimer's disease mouse models. Cell 142, 387-397.

[53] Xie M, Li Y, Wang SH, Yu QT, Meng X, Liao XM (2017) The involvement of NR2B and tau protein in MG132induced CREB dephosphorylation. J Mol Neurosci 62, 154-162.

[54] Baazaoui N, Iqbal K (2017) Prevention of dendritic and synaptic deficits and cognitive impairment with a neurotrophic compound. Alzheimers Res Ther $\mathbf{9}, 45$.

[55] Gomez-Ramos A, Podlesniy P, Soriano E, Avila J (2015) Distinct X-chromosome SNVs from some sporadic AD samples. Sci Rep 5, 18012.

[56] Gomez-Ramos A, Picher AJ, Garcia E, Garrido P, Hernandez F, Soriano E, Avila J (2017) Validation of suspected somatic single nucleotide variations in the brain of Alzheimer's disease patients. J Alzheimers Dis 56, 977-990.
[57] Marchetto MCN, Narvaiza I, Denli AM, Benner C, Lazzarini TA, Nathanson JL, Paquola ACM, Desai KN, Herai RH, Weitzman MD, Yeo GW, Muotri AR, Gage FH (2013) Differential L1 regulation in pluripotent stem cells of humans and apes. Nature 503, 525-529.

[58] Arendt T, Bruckner MK, Losche A (2015) Regional mosaic genomic heterogeneity in the elderly and in Alzheimer's disease as a correlate of neuronal vulnerability. Acta Neuropathol 130, 501-510.

[59] Sala Frigerio C, Lau P, Troakes C, Deramecourt V, Gele P, Van Loo P, Voet T, De Strooper B (2015) On the identification of low allele frequency mosaic mutations in the brains of Alzheimer's disease patients. Alzheimers Dement 11, 1265-1276.

[60] Sanchez-Mut JV, Aso E, Panayotis N, Lott I, Dierssen M, Rabano A, Urdinguio RG, Fernandez AF, Astudillo A, Martin-Subero JI, Balint B, Fraga MF, Gomez A, Gurnot C, Roux JC, Avila J, Hensch TK, Ferrer I, Esteller M (2013) DNA methylation map of mouse and human brain identifies target genes in Alzheimer's disease. Brain 136, 3018-3027.

[61] Yang SS, Zhang R, Wang G, Zhang YF (2017) The development prospection of HDAC inhibitors as a potential therapeutic direction in Alzheimer's disease. Transl Neurodegener $\mathbf{6}, 19$.

[62] Avila J, Perry G, Strange BA, Hernandez F (2015) Alternative neural circuitry that might be impaired in the development of Alzheimer disease. Front Neurosci 9, 145.

[63] Llorens-Martin M, Fuster-Matanzo A, Teixeira CM, JuradoArjona J, Ulloa F, Defelipe J, Rabano A, Hernandez F, Soriano E, Avila J (2013) GSK-3beta overexpression causes reversible alterations on postsynaptic densities and dendritic morphology of hippocampal granule neurons in vivo. Mol Psychiatry 18, 451-460.

[64] Wyss-Coray T (2016) Ageing, neurodegeneration and brain rejuvenation. Nature 539, 180-186. 